\title{
Variations in Low Electrical Stimulator Voltage Settings Minimally Influence Beef Longissimus Muscle Slice Shear Force Values
}

\author{
Travis S. Arp ${ }^{1}$, Emily Rice ${ }^{1}$, Dale R. Woerner ${ }^{1,2}$, Kenichi Katoh ${ }^{1}$, Gary C. Smith ${ }^{1}$, \\ Keith E. Belk ${ }^{1}$, and Mahesh N. Nair ${ }^{1 *}$ \\ ${ }^{1}$ Center for Meat Safety \& Quality, Department of Animal Sciences, Colorado State University, Fort Collins, CO 80523, USA \\ ${ }^{2}$ Department of Animal and Food Sciences, Texas Tech University, Lubbock, TX 79409-2141, USA \\ *Corresponding author. Email: mahesh.narayanan_nair@colostate.edu (Mahesh N. Nair)
}

\begin{abstract}
The objective of the current study was to evaluate the effect of differing electrical stimulation (ES) voltage levels on beef longissimus muscle tenderness, postmortem temperature, $\mathrm{pH}$ decline, and carcass quality. Beef carcasses from 3 commercial beef processing plants (A, B, C) were exposed to 3 varying voltage levels: (1) control (no ES), (2) ES level 1 (ES1; $60 \mathrm{~Hz}$ for $17 \mathrm{~s}$ each at 16,20,24, and $28 \mathrm{~V}$ ), and (3) ES level 2 (ES2; $60 \mathrm{~Hz}$ for $17 \mathrm{~s}$ each at 25, 35, 45, and 55 V) prior to chilling. Ninety beef carcasses were selected from each of the 3 plants, and within a carcass, paired sides were randomly assigned to one of $3 \mathrm{ES}$ treatments $(n=60$ sides/treatment/plant). The results indicated that ES affected $(P<0.05)$ muscle $\mathrm{pH}$ at $3 \mathrm{~h}$ postmortem in 2 of the 3 plants. However, ES did not affect $(P>0.05) \mathrm{pH}$ at the time of grading (postrigor). Although the slice shear force (SSF) values were lower $(P<0.05)$ for ES steaks compared with controls, voltage did not affect $(P>0.05)$ SSF values. Variation in SSF was observed among the plants $(P<0.05)$, with steaks from Plant $C$ having greater $(P<0.05)$ SSF values compared with steaks from Plants A and $\mathrm{B}$, which exhibited similar $(P>0.05)$ SSF values. Overall, although ES steaks had lower SSF values compared with control steaks, the lack of difference in postmortem tenderness between ES1 and ES2 voltage settings indicated that the low ES voltages minimally influenced SSF values.
\end{abstract}

Key words: beef, electrical stimulation, tenderness, voltage settings

Meat and Muscle Biology 5(1): 32, 1-7 (2021)

doi:10.22175/mmb.12549

Submitted 3 May 2021

Accepted 6 June 2021

\section{Introduction}

Flavor and tenderness are two significant drivers of consumer eating satisfaction of beef (Savell et al., 1987; Miller et al., 2001; Killinger et al., 2004; Behrends et al., 2005a, 2005b). Although the National Beef Tenderness Surveys have reported no significant increase in the tenderness of beef steaks after 2006, inconsistent tenderness has been identified as a major quality issue by purveyors, restaurateurs, and supermarkets (Smith et al., 2006; Voges et al., 2007; Igo et al., 2015; Martinez et al., 2017).

Electrical stimulation (ES) is one of the postharvest intervention strategies that can improve tenderness in beef (Savell et al., 1978a; McKeith et al., 1981; Roeber et al., 2000). ES also enhances lean color, texture, and lean maturity of beef carcasses (Savell et al., 1978a; Cross, 1979; Roeber et al., 2000). Improvement in tenderness with ES has been attributed to increased adenosine triphosphate (ATP) metabolism and prevention of sarcomere shortening during carcass chilling (Gilbert and Davey, 1976; Agbeniga and Webb, 2021). Moreover, the contractile forces during ES can damage cellular integrity and liberate calcium from the sarcoplasmic reticulum, which can activate the calpain system to enhance the postmortem tenderization process (Ducastaing et al., 1985; Uytterhaegen et al., 1992).

The voltage used for ES can vary among different commercial beef processing facilities ranging from voltage as high as 450 to $500 \mathrm{~V}$ to very low voltages 
(40 to $45 \mathrm{~V}$ ). In general, most large-scale commercial beef processing facilities in the United States utilize low- to medium-voltage ES. Previous research has reported that either high- or low-voltage ES can improve beef tenderness, with the greatest improvement observed in high-voltage ES carcasses (Savell, 1985). However, the effect of commercially implemented ES voltages on beef quality has not been evaluated yet. Therefore, the objective of the current study was to evaluate the effect of different voltage levels of ES on beef longissimus muscle (LM) tenderness.

\section{Materials and Methods}

\section{Experimental design and treatments}

Beef carcasses $(N=270)$ were selected from 3 commercial plants located in Nebraska, Colorado, and Texas (90 beef carcasses per plant) at the time of slaughter. Within a carcass, paired sides were assigned to one of 3 treatment combinations, resulting in 180 replicates per treatment: (1) control and ES level 1 (ES1); (2) control and ES level 2 (ES2); or (3) ES1 and ES2. For this study, controls had no ES; ES1 had voltages of 16, 20, 24, and $28 \mathrm{~V}$ for $17 \mathrm{~s}$ each; and ES2 had voltages of $25,35,45$, and $55 \mathrm{~V}$ for $17 \mathrm{~s}$ each immediately following the carcass hot water wash, approximately 30 min postmortem, just before carcass chilling. All carcasses traveled through these 4 zones (17 $\mathrm{s}$ in each zone) of $60-\mathrm{Hz}$ ES in the commercial processing facilities, immediately after which the carcasses were spray-chilled for the first $8 \mathrm{~h}$ of the chill period.

\section{Temperature and $\mathrm{pH}$ measurement}

Internal temperature and $\mathrm{pH}$ of the $\mathrm{LM}$ were measured immediately following ES, at $3 \mathrm{~h}$ postmortem, and at the time of grading (between 36 and $48 \mathrm{~h}$ postmortem depending on the standard practice for the plant) using a Type K thermocouple (Model 34040, Atkins Technical, Inc., Gainesville, FL) and a portable pH meter (Model HI 99161, Hanna Instruments, Woonsocket, RI). Temperature and $\mathrm{pH}$ of LM were measured at the approximate geometric center of the LM, immediately posterior to the lumbar vertebra of the 13 th rib.

\section{Carcass yield grade and color data}

Upon the conclusion of 36- to 48-h chilling, the carcasses were ribbed and graded. Marbling score, skeletal maturity, and lean maturity were determined by a USDA grader. Preliminary yield grade (PYG), adjusted PYG, and LM area (LMA) were determined by trained Colorado State University personnel. In addition, adjusted hot carcass weight (HCW) and percentage kidney, pelvic, and heart (KPH) fat were also recorded. The LM lean and external fat color were measured at the 12th and 13th rib interface for each side following proper bloom time, using a portable spectrophotometer equipped with a 6-mm aperture (MiniScan XE; Hunter Associates Laboratory, Reston, VA) following the standardization procedures outlined for the spectrophotometer (illuminant A and $10^{\circ}$ standard observer). Three individual color measurements were averaged to obtain a single value for instrumental lightness $\left(L^{*}\right)$, redness $\left(a^{*}\right)$, and yellowness $\left(b^{*}\right)$.

\section{Sample collection and tenderness measurement}

LM sections $(5.08 \mathrm{~cm})$ removed from the anterior end of the strip loins (Institutional Meat Purchase Specifications \#180) were vacuum packaged and transported on ice to the Colorado State University Meat Laboratory, after which they were aged for $14 \mathrm{~d}$ $\left(-1^{\circ} \mathrm{C}\right)$. After aging (never frozen), samples were fabricated to $2.54-\mathrm{cm}$-thick steaks for slice shear force (SSF) measurement. The steaks were stored at $2^{\circ} \mathrm{C}$ to ensure that precooking internal temperatures were between $1^{\circ} \mathrm{C}$ and $5^{\circ} \mathrm{C}$. Steaks were cooked on electric grills (George Forman Grilling Machine GRP90WGP, Salton Inc., Lake Forest, IL) to an internal temperature of $70^{\circ} \mathrm{C}$. Peak internal temperature measurements were recorded from the geometric center of each steak using a Type $\mathrm{K}$ thermocouple (model 34040, Atkins Technical, Inc.).

SSF measurement was conducted immediately after the postcooking measurements were complete using the shear force protocol by Shackelford et al. (1999). Briefly, a 1-cm-thick, 5-cm-long slice was removed from each cooked steak parallel to the longitudinal orientation of the muscle fibers and then sheared perpendicular to the muscle fiber orientation using a universal testing machine (model 4443, Instron, Norwood, MA) equipped with a flat, blunt-end blade. A single peak SSF measurement was recorded for each steak.

\section{Statistical analysis}

A balanced incomplete block design was utilized to determine the effect of differing voltages of ES on beef $\mathrm{LM}$ tenderness, postmortem temperature and $\mathrm{pH}$ 
decline, and carcass quality with individual carcass serving as the block.

Data for SSF values, carcass characteristics, and temperature and $\mathrm{pH}$ decline rate were analyzed using the MIXED procedure of SAS (SAS Institute, Cary, $\mathrm{NC})$ with the individual side serving as the experimental unit. Data for $\mathrm{pH}$ and temperature were analyzed as repeated measures using the SAS MIXED procedure. Carcass identification was included as a random variable for one-time measurements. Whole carcass identification and side identification within the whole carcass were included as a random variable for repeated measures ( $\mathrm{pH}$ and temperature data). For all analyses, the Kenward-Roger approximation was used to calculate denominator degrees of freedom, and least-squares means were separated using the PDIFF option at a significance level of $P<0.05$.

\section{Results}

\section{Carcass characteristics, longissimus muscle color, and subcutaneous fat color}

There was no treatment $\times$ plant interaction $(P>$ $0.05)$ for carcass characteristics. Furthermore, the voltage setting of ES did not influence $(P>0.05) \mathrm{HCW}$, $\mathrm{PYG}, \mathrm{LMA}, \mathrm{KPH}$, fat $L^{*}$, or fat $a^{*}$ measurements (Table 1). However, lean $a^{*}$ measurements were affected by the treatment, with ES carcass sides (both

Table 1. Least-squares means and standard error of the mean (SEM) for carcass characteristics corresponding to the main effect of electrical stimulation (ES) treatment ${ }^{1}$

\begin{tabular}{lccccc}
\hline & \multicolumn{3}{c}{ ES Treatment } & & \\
\cline { 2 - 4 } Trait & Control $^{1}$ & ES1 & ES2 & SEM & $P$ Value \\
\hline Hot Carcass Weight, kg & 357 & 360 & 360 & 53 & 0.326 \\
$\begin{array}{l}\text { Adjusted Preliminary } \\
\text { Yield Grade }\end{array}$ & 3.24 & 3.26 & 3.26 & 0.03 & 0.440 \\
$\begin{array}{l}\text { Longissimus Muscle } \\
\text { Area, in }\end{array}$ & 13.30 & 13.36 & 13.30 & 0.10 & 0.574 \\
$\begin{array}{l}\text { Kidney, Pelvic, and } \\
\text { Heart Fat \% }\end{array}$ & 2.20 & 2.20 & 2.20 & 0.02 & 0.804 \\
Lean CIE Redness $\left(\boldsymbol{a}^{*}\right)$ & $10.71^{\mathrm{b}}$ & $11.06^{\mathrm{a}}$ & $11.27^{\mathrm{a}}$ & 0.16 & $<0.001$ \\
Fat CIE Lightness $\left(\boldsymbol{L}^{*}\right)$ & 68.46 & 68.21 & 67.96 & 0.30 & 0.312 \\
Fat CIE Redness $\left(\boldsymbol{a}^{*}\right)$ & 0.14 & 0.14 & -0.01 & 0.10 & 0.184 \\
\hline
\end{tabular}

${ }^{1}$ Control $=$ no ES; ES1 $=16,20,24$, and $28 \mathrm{~V}$ for $17 \mathrm{~s}$ each; $\mathrm{ES} 2=25,35$, 45 , and $55 \mathrm{~V}$ for $17 \mathrm{~s}$ each.

${ }^{2} \mathrm{ES}$ treatment $\times$ plant interaction is presented in Table 3 for lean Commission Internationale de $1^{\prime}$ Eclairage (CIE) $L^{*}$ and $b^{*}$ and fat CIE $b^{*}$.

${ }^{\mathrm{a}, \mathrm{b}}$ Means in the same row without a common superscript differ $(P<0.05)$.
ES1 and ES2) having greater redness compared with controls (Table $1 ; P>0.05$ ).

Least-squares means summarizing the effect of the plant on carcass characteristics are presented in Table 2. There was no difference in $\mathrm{HCW}$ among the plants $(P>0.05)$. Carcasses in Plants $\mathrm{A}$ and $\mathrm{C}$ were not different in adjusted PYG estimates $(P>0.05)$, whereas carcasses in Plant B were leaner $(P<0.05)$. Carcasses in Plant $\mathrm{C}$ had greater $(P<0.05)$ LMA than carcasses in Plant $\mathrm{B}$, whereas carcasses in Plant A were intermediary, having similar $(P>0.05)$ LMA to both Plants B and C. Carcasses from Plant C had the least $(P<0.05) \mathrm{KPH}$, whereas carcasses from Plants A and B were not different $(P>0.05)$ in $\mathrm{KPH}$ percentages.

There was a treatment $\times$ plant interaction for marbling scores, overall maturity, lean Commission Internationale de $1^{\prime}$ Eclairage (CIE) $L^{*}$, lean CIE $b^{*}$, and fat CIE $b^{*}$ (Table 3). ES did not influence $(P>$ $0.05)$ marbling scores in Plants $\mathrm{A}$ and $\mathrm{B}$, whereas in Plant $\mathrm{C}$, carcasses receiving ES2 had higher $(P<$ $0.05)$ mean marbling scores compared with controls. There was also a difference $(P<0.05)$ in marbling scores in Plant $\mathrm{C}$, where carcasses treated with ES2 had greater $(P<0.05)$ marbling scores compared with control carcasses. Carcasses treated with ES1 were not different $(P>0.05)$ from both control and ES2 carcasses for marbling scores in Plant C. Both Plants A and $\mathrm{B}$ were not different in marbling scores $(P>$ $0.05)$ across ES treatments. Additionally, Plants A and $\mathrm{B}$ showed no differences $(P>0.05)$ between ES

Table 2. Least-squares means and standard error of the mean (SEM) for carcass characteristics corresponding to the main effect of plant

\begin{tabular}{|c|c|c|c|c|c|}
\hline \multirow[b]{2}{*}{ Trait } & \multicolumn{4}{|c|}{ Plant } & \multirow[b]{2}{*}{$P$ Value } \\
\hline & A & $\mathrm{B}$ & $\mathrm{C}$ & SEM & \\
\hline Hot Carcass Weight, kg & 363 & 363 & 361 & 34 & 0.362 \\
\hline $\begin{array}{l}\text { Adjusted Preliminary } \\
\text { Yield Grade }\end{array}$ & $3.30^{\mathrm{a}}$ & $3.15^{\mathrm{b}}$ & $3.32^{\mathrm{a}}$ & 0.05 & 0.011 \\
\hline $\begin{array}{l}\text { Longissimus Muscle } \\
\text { Area, in }{ }^{1}\end{array}$ & $13.44^{\mathrm{ab}}$ & $13.01^{\mathrm{b}}$ & $13.52^{\mathrm{a}}$ & 0.16 & 0.048 \\
\hline $\begin{array}{l}\text { Kidney, Pelvic, and } \\
\text { Heart Fat } \%\end{array}$ & $2.23^{\mathrm{a}}$ & $2.31^{\mathrm{a}}$ & $2.05^{\mathrm{b}}$ & 0.05 & $<0.001$ \\
\hline Lean CIE Redness $\left(a^{*}\right)$ & $11.52^{\mathrm{a}}$ & $10.81^{\mathrm{b}}$ & $10.73^{b}$ & 0.24 & 0.039 \\
\hline Fat CIE Lightness $\left(L^{*}\right)$ & $68.44^{b}$ & $69.81^{\mathrm{a}}$ & $66.37^{\mathrm{c}}$ & 0.41 & $<0.001$ \\
\hline Fat CIE Redness $\left(a^{*}\right)$ & $0.61^{\mathrm{a}}$ & $-0.59^{\mathrm{b}}$ & $0.25^{\mathrm{a}}$ & 0.14 & $<0.001$ \\
\hline
\end{tabular}

${ }^{1}$ Electrical stimulation treatment $\times$ plant interaction is presented in Table 3 for lean Commission Internationale de 1'Eclairage (CIE) $L^{*}$ and $b^{*}$ and fat CIE $b^{*}$.

${ }^{\mathrm{a}-\mathrm{c}}$ Means in the same row without a common superscript $\operatorname{differ}(P<$ $0.05)$ 
Table 3. Least-squares means and standard error of the mean (SEM) for carcass characteristics corresponding to the electrical stimulation (ES) treatment ${ }^{1} \times$ plant interaction

\begin{tabular}{|c|c|c|c|c|c|c|c|c|c|c|c|}
\hline \multirow[b]{2}{*}{ Trait } & \multicolumn{3}{|c|}{ Plant A } & \multicolumn{3}{|c|}{ Plant B } & \multicolumn{3}{|c|}{ Plant C } & \multirow[b]{2}{*}{ SEM } & \multirow[b]{2}{*}{$P$ Value } \\
\hline & Control $^{1}$ & $\mathrm{ES} 1^{1}$ & $\mathrm{ES} 2^{1}$ & Control $^{1}$ & $\mathrm{ES} 1^{1}$ & $\mathrm{ES}^{1}{ }^{1}$ & Control $^{1}$ & $\mathrm{ES} 1^{1}$ & $\mathrm{ES} 2^{1}$ & & \\
\hline Marbling Score $^{2}$ & 399 & 406 & 406 & 456 & 451 & 449 & $336^{\mathrm{b}}$ & $346^{\mathrm{ab}}$ & $352^{\mathrm{a}}$ & 9.39 & 0.043 \\
\hline Overall Maturity $^{3}$ & 174 & 173 & 172 & 166 & 165 & 168 & $172^{\mathrm{a}}$ & $169^{\mathrm{b}}$ & $167^{\mathrm{b}}$ & 2.65 & 0.026 \\
\hline Lean CIE $L^{*}$ & $35.55^{\mathrm{b}}$ & $37.27^{\mathrm{a}}$ & $37.04^{\mathrm{a}}$ & $37.85^{\mathrm{b}}$ & $39.01^{\mathrm{a}}$ & $37.35^{\mathrm{b}}$ & 36.24 & 36.74 & 36.44 & 0.45 & 0.027 \\
\hline Lean CIE $b^{*}$ & $11.51^{\mathrm{b}}$ & $12.24^{\mathrm{a}}$ & $12.61^{\mathrm{a}}$ & 11.56 & 12.16 & 11.84 & $10.75^{\mathrm{b}}$ & $11.39^{\mathrm{a}}$ & $11.01^{\mathrm{ab}}$ & 0.26 & 0.015 \\
\hline Fat CIE $b^{*}$ & 6.87 & 6.94 & 6.63 & $6.75^{\mathrm{b}}$ & $7.53^{\mathrm{a}}$ & $6.31^{\mathrm{c}}$ & 5.88 & 5.77 & 5.77 & 0.23 & 0.002 \\
\hline
\end{tabular}

${ }^{1}$ Control $=$ no ES; ES1 $=16,20,24$, and $28 \mathrm{~V}$ for $17 \mathrm{~s}$ each; $\mathrm{ES} 2=25,35,45$, and $55 \mathrm{~V}$ for $17 \mathrm{~s}$ each.

${ }^{2}$ Slight $=300$ to 399 ; small $=400$ to 499 ; modest $=500$ to 599 .

3“ A" maturity $=100$ to 199 .

${ }^{\mathrm{a}-\mathrm{c}} \mathrm{Means}$ in the same row, within a plant, without a common superscript $\operatorname{differ}(P<0.05)$.

$\mathrm{CIE}=$ Commission Internationale de $1^{\prime}$ Eclairage.

treatments for overall maturity, whereas control carcasses in Plant $\mathrm{C}$ had greater $(P<0.05)$ maturity scores than both ES treatments.

In Plant A, carcasses receiving ES1 and ES2 had higher $(P<0.05)$ lean $L^{*}$ values than controls (Table 3). In Plant B, carcasses receiving ES1 produced the highest $(P<0.05)$ lean $L^{*}$ values. The ES did not affect $(P>0.05)$ lean $L^{*}$ values in the Plant $\mathrm{C}$ facility. Carcasses from Plant A, regardless of ES stimulation level, had greater $(P>0.05) b^{*}$ values than control carcasses. Additionally, carcasses from Plant $\mathrm{C}$ that received ES1 had greater $(P<0.05)$ lean $b^{*}$ values than control carcasses, with ES2 carcasses being similar $(P>0.05)$ to both. There were no differences $(P>$ $0.05)$ in fat $b^{*}$ values between ES treatments for Plants A and C. Carcasses treated with ES1 in Plant
B had the greatest $(P<0.05)$ fat $b^{*}$ values, with ES2 carcasses' fat $b^{*}$ values being the least $(P<0.05)$.

\section{Temperature and $\mathrm{pH}$}

There was a treatment $\times$ plant $\times$ time interaction $(P<0.0001)$ for temperature, $\mathrm{pH}$, and the rate of $\mathrm{pH}$ decline (Table 4). Control carcasses had greater $\mathrm{pH}$ $(P<0.05)$ than ES2 carcasses in all 3 plants immediately following ES. At $3 \mathrm{~h}$ postmortem, the effect of $\mathrm{ES}$ on $\mathrm{pH}$ was evident $(P<0.05)$ in Plants $\mathrm{A}$ and $\mathrm{B}$, where the $\mathrm{pH}$ of control carcasses was greater $(P<$ $0.05)$ than both ES carcass treatments. However, there was no difference $(P>0.05)$ in $\mathrm{pH}$ between the treatments at $3 \mathrm{~h}$ in Plant $\mathrm{C}$. The ultimate $\mathrm{pH}$ collected at the time of grading was not affected by ES $(P>0.05)$ in

Table 4. Least-squares means for $\mathrm{pH}$ and temperature of carcass at each time point, and rate of $\mathrm{pH}$ decline $(\mathrm{pH}$ units $/ \mathrm{h})$ of carcass corresponding to the electrical stimulation $(\mathrm{ES})$ treatment ${ }^{1} \times$ plant $\times$ time interaction $(P<0.0001)$

\begin{tabular}{|c|c|c|c|c|c|c|c|c|c|c|}
\hline & \multirow[b]{2}{*}{ Time } & \multicolumn{3}{|c|}{ Plant A } & \multicolumn{3}{|c|}{ Plant B } & \multicolumn{3}{|c|}{ Plant C } \\
\hline & & Control $^{1}$ & $\mathrm{ES} 1^{1}$ & $\mathrm{ES}^{1}{ }^{1}$ & Control $^{1}$ & $\mathrm{ES} 1^{1}$ & $\mathrm{ES} 2^{1}$ & Control $^{1}$ & $\mathrm{ES}^{1}{ }^{1}$ & $\mathrm{ES} 2^{1}$ \\
\hline \multirow[t]{3}{*}{ pH } & $\mathrm{ES}^{2}$ & $6.82^{\mathrm{a}}$ & $6.75^{\mathrm{ab}}$ & $6.72^{\mathrm{b}}$ & $6.93^{\mathrm{a}}$ & $6.73^{\mathrm{b}}$ & $6.73^{b}$ & $6.70^{\mathrm{a}}$ & $6.73^{\mathrm{a}}$ & $6.59^{\mathrm{b}}$ \\
\hline & $3 \mathrm{~h}^{3}$ & $6.38^{\mathrm{a}}$ & $6.14^{\mathrm{b}}$ & $6.15^{\mathrm{b}}$ & $6.32^{\mathrm{a}}$ & $6.02^{\mathrm{b}}$ & $5.88^{\mathrm{c}}$ & 6.02 & 5.93 & 5.98 \\
\hline & Grade $^{4}$ & 5.34 & 5.31 & 5.31 & $5.27^{\mathrm{a}}$ & $5.24^{\mathrm{b}}$ & $5.25^{\mathrm{ab}}$ & 5.35 & 5.35 & 5.35 \\
\hline \multirow[t]{3}{*}{ pH Decline Rate } & ES to $3 \mathrm{~h}$ & $-0.134^{\mathrm{a}}$ & $-0.201^{\mathrm{b}}$ & $-0.185^{\mathrm{b}}$ & $-0.195^{\mathrm{a}}$ & $-0.225^{\mathrm{b}}$ & $-0.271^{\mathrm{c}}$ & $-0.207^{\mathrm{a}}$ & $-0.250^{\mathrm{b}}$ & $-0.181^{\mathrm{a}}$ \\
\hline & $3 \mathrm{~h}$ to grade & -0.018 & -0.008 & -0.013 & -0.026 & -0.017 & -0.010 & -0.011 & -0.007 & -0.008 \\
\hline & ES to grade & -0.025 & -0.010 & -0.023 & -0.040 & -0.034 & -0.032 & -0.024 & -0.024 & -0.020 \\
\hline \multirow[t]{3}{*}{ Temperature, ${ }^{\circ} \mathbf{C}$} & ES & 41.4 & 41.0 & 41.3 & 40.1 & 40.5 & 40.6 & 41.4 & 41.2 & 40.8 \\
\hline & $3 \mathrm{~h}$ & 31.5 & 31.6 & 32.0 & 29.8 & 29.6 & 30.1 & 30.0 & 29.8 & 29.7 \\
\hline & Grade & 1.2 & 1.2 & 1.2 & 3.0 & 3.0 & 2.8 & 0.2 & 0.3 & 0.3 \\
\hline
\end{tabular}

${ }^{1}$ Control $=$ no ES; ES1 $=16,20,24$, and $28 \mathrm{~V}$ for $17 \mathrm{~s}$ each; ES2 $=25,35,45$, and $55 \mathrm{~V}$ for $17 \mathrm{~s}$ each.

${ }^{2}$ Time "ES" is immediately following application of ES

${ }^{3}$ Time " $3 \mathrm{~h}$ " is $3 \mathrm{~h} \pm 10 \mathrm{~min}$ postmortem.

${ }^{4}$ Time "Grade" is at the time of grading (between 36 and $48 \mathrm{~h}$ postmortem).

${ }^{\mathrm{a}-\mathrm{c}}$ Means in the same row, within a plant, without a common superscript $\operatorname{differ}(P<0.05)$. 
any of the plants. In Plants A and B, control carcasses had slower $(P<0.05)$ rates of $\mathrm{pH}$ decline than carcasses receiving ES1 and ES2 treatments. However, this difference was not observed $(P>0.05)$ in Plant $\mathrm{C}$, where control and ES2 exhibited a similar $(P<$ $0.05)$ rate of $\mathrm{pH}$ decline. Additionally, the temperature at ES, at $3 \mathrm{~h}$ postmortem, and at grading was not influenced $(P>0.05)$ by the treatments or plants.

\section{Longissimus tenderness}

There was no ES $\times$ plant interaction for SSF values $(P>0.05)$. However, tenderness was influenced by the ES and the processing plant $(P<0.05)$. Irrespective of the voltage setting, ES decreased $(P<0.05)$ the SSF values compared with the controls (Table 5). Additionally, Plant $\mathrm{C}$ had the greatest $(P<0.05) \mathrm{SSF}$ values (Table 6).

\section{Discussion}

\section{Carcass quality characteristics}

In the current study, there was no difference in marbling score between the control and ES carcasses at 36 to $48 \mathrm{~h}$ postmortem in 2 of the 3 plants. However, in Plant $\mathrm{C}$, there was an increase in marbling score as ES increased. The results from Plant $\mathrm{C}$ are supported by Savell et al. (1978a, 1978b), who reported that ES could affect marbling scores because of the earlier "setting up" of the intramuscular fat in LM. In addition,

Table 5. Least-squares means and standard error of the mean (SEM) for the effect of electrical stimulation (ES) treatment on slice shear force (SSF)

\begin{tabular}{|c|c|c|c|c|c|}
\hline & \multicolumn{3}{|c|}{ Treatments $^{1}$} & \multirow[b]{2}{*}{ SEM } & \multirow[b]{2}{*}{$P$ Value } \\
\hline & Control & $\mathrm{ES} 1^{1}$ & $\mathrm{ES} 2^{1}$ & & \\
\hline $\mathrm{SSF}, \mathrm{kg}$ & $22.88^{\mathrm{a}}$ & $20.60^{b}$ & $20.13^{b}$ & 0.47 & $<0.001$ \\
\hline
\end{tabular}

Table 6. Least-squares means and standard error of the mean (SEM) for the effect of plant on slice shear force (SSF)

\begin{tabular}{|c|c|c|c|c|c|}
\hline & \multicolumn{3}{|c|}{ Plant } & \multirow[b]{2}{*}{ SEM } & \multirow[b]{2}{*}{ P Value } \\
\hline & A & B & $\mathrm{C}$ & & \\
\hline SSF, kg & $19.91^{b}$ & $20.63^{b}$ & $23.36^{\mathrm{a}}$ & 0.64 & $<0.0001$ \\
\hline
\end{tabular}

Calkins et al. (1980) also reported higher-quality grades associated with ES carcasses. On the other hand, results from Plants A and B are supported by a later study by Savell (1985), in which the differences in marbling scores between ES and non-ES sides were negligible after chilling for more than $48 \mathrm{~h}$ postmortem. The variation among plants could be associated with the 12-h spread in chilling times prior to grading among the plants.

Lean color is one of the quality attributes associated with fresh beef and plays a key role in consumer purchasing decisions and USDA quality grades (Killinger et al., 2004; Ramanathan et al., 2020). In addition to marbling, lean color accounts for a portion of the overall quality grade in the United States. Lean maturity of beef is determined in part by anterior LM color (Wulf and Wise, 1999). Therefore, objective color measurement $\left(L^{*}, a^{*}\right.$, and $\left.b^{*}\right)$ of LM served as a more consistent indicator of actual differences among treatments and plants. Previous studies reported that application of ES resulted in the appearance of more youthfulness of lean, more desirability of overall maturity scores, and improved CIE $L^{*}, a^{*}$, and $b^{*}$ values of lean color compared with the controls (McKeith et al., 1981; Tatum et al., 1999; Roeber et al., 2000; McKenna et al., 2004; Nazli et al., 2010; Agbeniga and Webb, 2021). This is relatively consistent with the findings of this study, as carcasses receiving ES had a redder lean color compared with control carcasses. This reinforces the hypothesis that ES can improve the color of beef steaks, and, more notably, this is still demonstrated at lower voltages used in this study.

\section{Temperature and $\mathrm{pH}$}

In the current study, the treatment $\times$ plant $\times$ time interaction for temperature, $\mathrm{pH}$, and their rate of decline indicated that the $3 \mathrm{ES}$ treatments produced differing effects on these parameters depending on the plant in which the carcass was processed and the time of measurement. Control carcasses had a higher $\mathrm{pH}$ compared with carcasses treated with ES2 immediately after stimulation, but there was no difference in final $\mathrm{pH}$ among treatments in 2 of the 3 plants in the study. ES causes the acceleration of glycolysis, which leads to a more rapid $\mathrm{pH}$ decline. Similar results were reported in multiple prior studies in which a more rapid $\mathrm{pH}$ decline with varying voltage settings was observed (Uytterhaegen et al., 1992; Hwang and Thompson, 2001; Zhang et al., 2019; Ji et al., 2021). Unlike other studies (Uytterhaegen et al., 1992; Hwang and Thompson, 2001), which reported an initial increase in temperature after ES as glycolysis began to 
accelerate, there was no temperature difference at any of the time points measured in this study regardless of plant. This lack of difference in temperature could be attributed to different applications and voltages used in each study. Hwang and Thompson (2001) used a similar voltage to the current study $(45 \mathrm{~V}, 10 \mathrm{~ms}$ on and $12 \mathrm{~ms}$ off at 36 pulses per second), but Uytterhaegen et al. (1992) used a much higher voltage for a much longer period of time $(600 \mathrm{~V}$ for $120 \mathrm{~s})$.

\section{Longissimus tenderness}

ES is employed in the beef industry to help reduce the incidence of cold shortening, which can negatively impact tenderness. Cold shortening occurs when the muscles are rapidly chilled prior to the onset of rigor mortis. ES prevents cold shortening by accelerated glycolysis and $\mathrm{pH}$ decline, ultimately causing an early onset of rigor mortis (Swatland, 1981). In addition to accelerating the glycolysis, ES could cause damage to the ultrastructure of the muscle, aiding in the further breakdown of the muscle during aging, ultimately increasing tenderness (Dransfield, 1994; Zhang et al., 2019).

Our results are in agreement with previous studies that also reported that ES improved tenderness of beef steaks (Savell et al., 1978a; Tatum et al., 1999; Roeber et al., 2000; Simmons et al., 2008; Aalhus et al., 2011; Zhang et al., 2019). However, our results indicated that voltage settings (ES1 vs. ES2) used in this study did not impact tenderness. Additionally, the SSF values varied among plants from which the LM steaks were collected. Steaks from Plant $C$ had the greatest toughness, whereas steaks from Plants A and B exhibited similar SSF values. The tenderness difference among plants could be due to biological variation in cattle sourced for different plants as well as the minor variations in the chilling practices. In partial support, there were minor variations in the $\mathrm{pH}$ decline rates among the plants. The rapid $\mathrm{pH}$ decline along with slow chilling could adversely affect tenderness because of potential heat shortening of sarcomeres (Takahashi et al., 1987).

\section{Conclusions}

Regardless of the voltage settings, ES steaks had lower SSF values compared with control steaks. However, the lack of difference in postmortem tenderness between the voltage settings used in this study indicated that there was no additional value in increasing the ES voltage at low levels. Moreover, the variation in tenderness among plants indicated that the ES setting might need to be standardized for each plant depending on the cattle source and chiller settings in order to achieve consistent quality improvements.

\section{Literature Cited}

Aalhus, J. L., S. D. M. Jones, D. R. Best, W. M. Robertson, and S. Lutz. 2011. The efficacy of high and low voltage electrical stimulation under different chilling regimes. Can. J. Anim. Sci. 74:433-442. https://doi.org/10.4141/cjas94-062.

Agbeniga, B., and E. C. Webb. 2021. Color attributes and glycolytic energy metabolites of meat from light and heavy bovine feedlot carcasses stimulated with low-voltage electricity. Meat Muscle Biol. 5. https://doi.org/10.22175/mmb.9493 (in press).

Behrends, J. M., K. J. Goodson, M. Koohmaraie, S. D. Shackelford, T. L. Wheeler, W. W. Morgan, J. O. Reagan, B. L. Gwartney, J. W. Wise, and J. W. Savell. 2005a. Beef customer satisfaction: Factors affecting consumer evaluations of calcium chloride-injected top sirloin steaks when given instructions for preparation. J. Anim. Sci. 83:2869-2875. https://doi.org/10. 2527/2005.83122869x.

Behrends, J. M., K. J. Goodson, M. Koohmaraie, S. D. Shackelford, T. L. Wheeler, W. W. Morgan, J. O. Reagan, B. L. Gwartney, J. W. Wise, and J. W. Savell. 2005b. Beef customer satisfaction: USDA quality grade and marination effects on consumer evaluations of top round steaks. J. Anim. Sci. 83:662-670. https://doi.org/10.2527/2005.833662x.

Calkins, C. R., J. W. Savell, G. C. Smith, and C. E. Murphey. 1980. Quality-indicating characteristics of beef as affected by electrical stimulation and postmortem chilling time. J. Food Sci. 45:1330 1332. https://doi.org/10.1111/j.1365-2621.1980.tb06548.x.

Cross, H. R. 1979. Effects of electrical stimulation on meat tissue and muscle properties-A review. J. Food Sci. 44:509-514. https://doi.org/10.1111/j.1365-2621.1979.tb03823.x.

Dransfield, E. 1994. Optimisation of tenderisation, ageing and tenderness. Meat Sci. 36:105-121. https://doi.org/10.1016/ 0309-1740(94)90037-X.

Ducastaing, A., C. Valin, J. Schollmeyer, and R. Cross. 1985. Effects of electrical stimulation on post-mortem changes in the activities of two Ca dependent neutral proteinases and their inhibitor in beef muscle. Meat Sci. 15:193-202. https://doi. org/10.1016/0309-1740(85)90075-0.

Gilbert, K. V., and C. L. Davey. 1976. Carcass electrical stimulation and early boning of beef. New Zeal. J. Agr. Res. 19:429-434. https://doi.org/10.1080/00288233.1976.10420971.

Hwang, I. H., and J. M. Thompson. 2001. The effect of time and type of electrical stimulation on the calpain system and meat tenderness in beef longissimus dorsi muscle. Meat Sci. 58:135-144. https://doi.org/10.1016/S0309-1740(00)00141-8.

Igo, M. W., A. N. Arnold, R. K. Miller, K. B. Gehring, L. N. Mehall, C. L. Lorenzen, R. J. Delmore Jr., D. R. Woerner, B. E. Wasser, and J. W. Savell. 2015. Tenderness assessments of top loin steaks from retail markets in four U.S. cities. J. Anim. Sci. 93:4610-4616. https://doi.org/10.2527/jas. 2015-9085. 
Ji, X., X. Luo, L. Zhu, Y. Mao, X. Lu, X. Chen, D. L. Hopkins, and Y. Zhang. 2021. Effect of medium voltage electrical stimulation and prior ageing on beef shear force during superchilled storage. Meat Sci. 172:108320. https://doi.org/10.1016/j. meatsci.2020.108320.

Killinger, K. M., C. R. Calkins, W. J. Umberger, D. M. Feuz, and K. M. Eskridge. 2004. Consumer sensory acceptance and value for beef steaks of similar tenderness, but differing in marbling level. J. Anim. Sci. 82:3294-3301. https://doi.org/10.2527/ 2004.82113294x.

Martinez, H. A., A. N. Arnold, J. C. Brooks, C. C. Carr, K. B. Gehring, D. B. Griffin, D. S. Hale, G. G. Mafi, D. D. Johnson, C. L. Lorenzen, R. J. Maddock, R. K. Miller, D. L. VanOverbeke, B. E. Wasser, and J. W. Savell. 2017. National beef tenderness survey-2015: Palatability and shear force assessments of retail and foodservice beef. Meat Muscle Biol. 1:138-148. https://doi.org/10.22175/ mmb2017.05.0028.

McKeith, F. K., J. W. Savell, and G. C. Smith. 1981. Tenderness improvement of the major muscles of the beef carcass by electrical stimulation. J. Food Sci. 46:1774-1776. https://doi.org/ 10.1111/j.1365-2621.1981.tb04482.x.

McKenna, D. R., C. L. Lorenzen, K. D. Pollok, W. W. Morgan, W. L. Mies, J. J. Harris, R. Murphy, M. McAdams, D. S. Hale, and J. W. Savell. 2004. Interrelationships of breed type, USDA quality grade, cooking method, and degree of doneness on consumer evaluations of beef in Dallas and San Antonio, Texas, USA. Meat Sci. 66:399-406. https://doi. org/10.1016/s0309-1740(03)00126-8.

Miller, M. F., M. A. Carr, C. B. Ramsey, K. L. Crockett, and L. C. Hoover. 2001. Consumer thresholds for establishing the value of beef tenderness. J. Anim. Sci. 79:3062-3068. https://doi. org/10.2527/2001.79123062x.

Nazli, B., O. Cetin, E. B. Bingol, T. Kahraman, and O. Ergun. 2010. Effects of high voltage electrical stimulation on meat quality of beef carcasses. J. Anim. Vet. Adv. 9:556-560. https://doi. org/10.3923/javaa.2010.556.560.

Ramanathan, R., M. C. Hunt, R. A. Mancini, M. N. Nair, M. L. Denzer, S. P. Suman, and G. G. Mafi. 2020. Recent updates in meat color research: Integrating traditional and highthroughput approaches. Meat Muscle Biol. 4:1-24. https:// doi.org/10.22175/mmb.9598.

Roeber, D. L., R. C. Cannell, K. E. Belk, J. D. Tatum, and G. C. Smith. 2000. Effects of a unique application of electrical stimulation on tenderness, color, and quality attributes of the beef longissimus muscle. J. Anim. Sci. 78:1504-1509. https://doi.org/10.2527/2000.7861504x.

Savell, J. W. 1985. Industrial applications of electrical stimulation. In: A. M. Pearson and T. R. Dutson, editors, Advances in meat research: Volume 1 electrical stimulation. Springer Netherlands, Dordrecht. p. 219-236. https://doi.org/10. 1007/978-94-011-5939-5_7.

Savell, J. W., R. E. Branson, H. R. Cross, D. M. Stiffler, J. W. Wise, D. B. Griffin, and G. C. Smith. 1987. National consumer retail beef study: palatability evaluations of beef loin steaks that differed in marbling. J. Food Sci. 52:517-519. https://doi. org/10.1111/j.1365-2621.1987.tb06664.x.

Savell, J. W., G. C. Smith, and Z. L. Carpenter. 1978a. Beef quality and palatability as affected by electrical stimulation and cooler aging. J. Food Sci. 43:1666-1668. https://doi.org/10.1111/j. 1365-2621.1978.tb07383.x.

Savell, J. W., G. C. Smith, and Z. L. Carpenter. 1978b. Effect of electrical stimulation on quality and palatability of lightweight beef carcasses. J. Anim. Sci. 46:1221-1228. https:// doi.org/10.2527/jas1978.4651221x.

Shackelford, S. D., T. L. Wheeler, and M. Koohmaraie. 1999. Evaluation of slice shear force as an objective method of assessing beef longissimus tenderness. J. Anim. Sci. 77:2693-2699. https://doi.org/10.2527/1999.77102693x.

Simmons, N. J., C. C. Daly, T. L. Cummings, S. K. Morgan, N. V. Johnson, and A. Lombard. 2008. Reassessing the principles of electrical stimulation. Meat Sci. 80:110-122. https://doi.org/ 10.1016/j.meatsci.2008.05.006.

Smith, G. C., J. W. Savell, J. B. Morgan, and T. E. Lawrence. 2006. Final report of the National Beef Quality Audit-2005: A new benchmark for the U.S. beef industry. National Cattlemen's Beef Association, Centennial, CO.

Swatland, H. J. 1981. Cellular heterogeneity in the response of beef to electrical stimulation. Meat Sci. 5:451-455. https://doi.org/ 10.1016/0309-1740(81)90043-7.

Takahashi, G., S.-M. Wang, J. V. Lochner, and B. B. Marsh. 1987. Effects of 2-Hz and $60-\mathrm{Hz}$ electrical stimulation on the microstructure of beef. Meat Sci. 19:65-76. https://doi.org/10.1016/ 0309-1740(87)90100-8.

Tatum, J. D., K. E. Belk, M. H. George, and G. C. Smith. 1999. Identification of quality management practices to reduce the incidence of retail beef tenderness problems: Development and evaluation of a prototype quality system to produce tender beef. J. Anim. Sci. 77:2112-8. https://doi.org/10.2527/1999. $7782112 \mathrm{x}$

Uytterhaegen, L., E. Claeys, and D. Demeyer. 1992. The effect of electrical stimulation on beef tenderness, protease activity and myofibrillar protein fragmentation. Biochimie. 74:275-281. https://doi.org/10.1016/0300-9084(92)90126-Y.

Voges, K. L., C. L. Mason, J. C. Brooks, R. J. Delmore, D. B. Griffin, D. S. Hale, W. R. Henning, D. D. Johnson, C. L. Lorenzen, R. J. Maddock, R. K. Miller, J. B. Morgan, B. E. Baird, B. L. Gwartney, and J. W. Savell. 2007. National beef tenderness survey - 2006: Assessment of Warner-Bratzler shear and sensory panel ratings for beef from US retail and foodservice establishments. Meat Sci. 77:357-364. https:// doi.org/10.1016/j.meatsci.2007.03.024.

Wulf, D. M., and J. W. Wise. 1999. Measuring muscle color on beef carcasses using the $\mathrm{L}^{*} \mathrm{a}^{*} \mathrm{~b} *$ color space. J. Anim. Sci. 77:2418-2427. https://doi.org/10.2527/1999.7792418x.

Zhang, Y., X. Ji, Y. Mao, X. Luo, L. Zhu, and D. L. Hopkins. 2019. Effect of new generation medium voltage electrical stimulation on the meat quality of beef slaughtered in a Chinese abattoir. Meat Sci. 149:47-54. https://doi.org/10.1016/j.meatsci. 2018.11.011. 